\title{
Access to Higher Education in Brazil with Reference to Prouni
}

\author{
Abrahao Andre de Araujo (Corresponding author) \\ House of Representatives - Brazil \\ Palácio do Congresso Nacional, Praça dos Três Poderes, Brasília, DF. 70160900, Brazil \\ Tel: 55-613-216-0000 E-mail: dearaujo.abrahao@gmail.com
}

Received: November 22, 2011 Accepted: November 25, 2011 Published: March 1, 2012

doi:10.5539/hes.v2n1p32

URL: http://dx.doi.org/10.5539/hes.v2n1p32

\begin{abstract}
The purpose of this essay is to discuss the Prouni - University for All policy, which has been implemented in Brazil in an effort to increase access of the underprivileged to postsecondary education. In order to provide a better understanding of the problem, three points of interest are initially addressed: income inequality, illiteracy, and a brief review of the history of higher education in Brazil. The paper then mentions a few policies that were implemented in the 1990s, aiming to increase the number of institutions of higher education, and addresses the implementation of the Prouni program. Next, it presents three competing views on the policy at issue regarding investments in the private sector, quality in education, and student retention. Finally, it concludes by giving a few recommendations for improving access to education in the country.
\end{abstract}

Keywords: Prouni - university for all, Access to higher education in Brazil, Public policy

\section{Introduction}

Education in Brazil has a long history of neglect, and in order to provide a better assessment of Prouni - University for All — an educational policy regarding access to higher learning in the country—, this paper will initially address three points of interest: income inequality, illiteracy, and a brief review of the history of postsecondary education in Brazil.

\subsection{Income Inequality}

With regard to income distribution, Brazil has historically been one of the countries with the highest income concentration in the world. According to Civita (2009):

In 2001 the richest $20 \%$ had 27 times the income of the poorest $20 \% \ldots$ In 2008 the richest $10 \%$ of the population lived on more than $40 \%$ of the national income, whereas the poorest $40 \%$ survived with only $10 \%$ of that income. ... The percentage of families living on less than the monthly minimum wage, that is, about $\$ 100$, in 2008 was $22.6 \%$, approximately 38 million people. (p. 118)

\subsection{Illiteracy}

As a direct result of social inequality, adult illiteracy has been an issue in Brazil ever since colonial times. Contrary to Canada and the United States, for example, which were colonies of settlement, Brazil was a colony of exploitation. In a colony of settlement, families come to the new land in order to start a new life. There is a strong sense of commitment within the settling community. In a colony of exploitation, on the other hand, individuals are sent to the colony with the purpose of exploiting it for the metropolis. There is no commitment to the founding of a new nation. Furthermore, Brazil was colonized by catholic Portugal and therefore did not experience the protestant's idea that every individual has to be literate in order to read the Bible. Consequently, for centuries there never was any serious attempt in the country to educate the population.

It was only in the $20^{\text {th }}$ century that the first initiatives to fight illiteracy were taken. Youngster's and Adult education started in the early 1930s, while the country was undergoing important changes regarding industrialization and urbanization. The need for a qualified workforce gave rise to the establishment of the first educational programs. In the early 1960s, Paulo Freire devised the so called "Paulo Freire System" or "Method," which was a system of educational techniques that could be applied to all levels of formal and informal education (Niskier 1989, pp. 355-356). Even though the first results of the initiative were promising, the project was discontinued due to his political exile in 1964. In 1967, the Brazilian Literacy Movement was implemented. Its objectives were the eradication of illiteracy, the integration of literate people into society, and the empowerment of the less-privileged 
population in Brazil. In 1980, 25.5\% of Brazilians (age 15 or older) were illiterate. In 2000, the percentage was $13.6 \%$ (Ferraro, 2002, p. 34). In 2007 , the number had dropped to $10 \%$, the same percentage as today, according to Civita (2009, p. 216).

\subsection{Brief Review of the History of Postsecondary Education in Brazil}

Illiteracy is only a partial result of social inequality. Education as whole has always been neglected in Brazil, mainly due to social disparities. In that sense, Cunha (2000) has explained that during colonial times, from 1500 to 1808 - the year when the Portuguese Crown came to Rio de Janeiro-, the Jesuits were in charge of schooling, which consisted of courses in Portuguese customs and values, rhetoric and grammar. Universities were not allowed in the colony, and higher studies were limited to philosophy and theology, also in Jesuit schools. The transfer of the Portuguese administration to the country changed the status quo and gave rise to the establishment of other higher programs (pp.152-153).

In the $1820 \mathrm{~s}$, there was a slight expansion of institutions of higher education (IHEs) in Brazil, mainly because the government began to realize how important it was to have an educated elite in order to be politically independent. It is to this end that the first IHEs were established. Cunha (2000) has pointed out that in 500 years, since the first Portuguese settlers arrived, universities have existed in Brazil for less than 200 years, contrary to what happened in other South American Spanish colonies, where they were established in the $16^{\text {th }}$ century (p. 152).

Improvements in higher learning in the early $19^{\text {th }}$ century meant easier access to IHEs, as a result of changes in admission policies and of the increase in the number of institutions. At the beginning of the $20^{\text {th }}$ century, in the early 1930s, there was an attempt to organize education on a national basis in the country. New legislation was enacted promoting education, establishing more curricular as well as administrative autonomy and encouraging research and cultural diffusion. In 1969, the Basic Cycle for Higher Education Act (1969) was enacted. College students were required to attend general courses for one or two years before entering the professional cycle, when they had to decide what to major in. The entrance exam was unified and its previous format, that is, a different test for each course, was changed.

Despite the improvements, postsecondary education in Brazil remained a privilege during the 1960s. Paradoxically, the vast majority of the population could not afford to prepare for the entrance exams and were therefore banned from the good free-of-charge public universities. It was in this context that the country experienced unprecedented college privatization, still in progress today. Until the 1960s, public colleges accounted for more than half of all IHEs in the country. In 1990, according to INEP (2008), out of the 918 IHEs listed, 222 were public and 696, private.

It was in this complex context of income inequality, illiteracy, and historical educational neglect that in the 1990s the federal government, following guidelines recommended by Unesco and the World Bank, began implementing policies aiming to increase the number of IHEs, enrollment, and courses. In 1995, just before the Guideline and Base Act (LDB), which defined the National Educational Plan (PNE), had been implemented, 1.76 million people attended colleges in Brazil. In 2004, mostly as a result of the PNE, that number had risen to 4.16 million (IBGE, 2009). Castro (2006) has pointed out that "Policies adopted in Brazil at the beginning of the 1990s aimed to make the offer of higher education more flexible, thus diversifying IHEs and enabling more students to enroll" (p. 122).

\section{Prouni - University for All}

In an effort to continue to expand enrollment in postsecondary education, particularly of low-income young adults, in 2005 the federal government implemented the Prouni - University for All Act (2005). Prouni is a public policy that promotes the exchange of scholarships in private colleges and universities for exemption of federal taxes. According to Maculan, Ribeiro, and Haddad (2006):

Although participation is voluntary, the number of institutions engaged in the program is increasing. A total of 1,142 private schools engaged in the first year (2005) of the program. This number increased to 1,232 in the second year (2006). Each of these schools should offer a number of scholarships . . corresponding to approximately $10 \%$ of the number of its regularly paying students. The total exemption of federal taxes for the year 2005 amounted to approximately R \$ 105.6 millions (approximately US\$ 48 millions). (p. 9)

The scholarships provided by Prouni can be of two types, depending on the student's income. Maculan et al. (2006) explained that:

There are two types of scholarships: full (awarded to students whose family monthly earnings per capita amount to at most 1.5 times the minimum wage) and partial (50\% of the monthly fees, awarded to students whose monthly earnings per capita amount to at most three times the minimum wage). (p. 9) 
In accordance with MEC (2008), a total of 247,643 scholarships (153,126 full and 94,517 partial) were awarded in 2009. In the first semester of 2010 , the number was 164,596 scholarships $(85,208$ full and 79,388 partial $)$.

Still according to Maculan et al. (2006), whereas "traditionally, the Brazilian public federal university system welcomes approximately 125,000 new students every year, with the creation of Prouni more than 120,000 new openings are being created every year at private schools through the new tax-funded scholarships" (p. 9). As a result of these policies, which began with the implementation of the LDB in 1995, the total number of students enrolled in IHEs in Brazil had risen to 5.53 million in 2008, according to Civita (2009, p. 222).

\section{Competing Views}

In spite of the increased enrollment in higher education in the country, there are competing views on the program. Three major issues are: the fact that the government has chosen to use the private sector to address the problem instead of investing more in public universities; the problem of quality in education; and the fact that the program addresses only the question of enrollment and does not pay the necessary attention to student retention. In relation to the first issue-namely, stimulating enrollment in the private sector instead of investing in the public universities - McCowan (2007) has pointed out that:

Despite the high demand for higher education in Brazil, there is considerable spare capacity in the system, as many places in private universities go unfilled due to inability of students to pay the fees. . . The idea of Prouni is to encourage these universities to allocate their unfilled places free of charge to low-income students in return for exemption from tax payments. ...Yet there has been strong opposition to the plan from university professors, rectors and students, who believe that the money spent (or rather the money not collected) would be better used in the public universities. (p. 589)

Mancebo (2004), in turn, has argued that by promoting the relocation of public money to the private sector, Prouni will necessarily reduce investments in public higher education (pp. 852-853). Cunha and Pinto (2009), for their part, have claimed that "Prouni is an attempt to invest public money in private colleges. . . What the government should do is increase the capacity of the public sector and provide for its efficiency" (p. 582).

In the same sense, Carvalho (2006) has contended that:

The underprivileged need not only full or partial scholarship in order to study, but also other conditions that only the public institutions can still offer, such as transportation, housing, subsidized food, medical assistance available at the university hospitals, and work and research scholarships. (p. 993)

Closely related to the issue of promoting enrollment in private colleges rather than in public universities, is the question of quality. According to Algebaile (2007):

Although [Prouni] seems to be an overarching program, the offer increase has not been accompanied by quality. On the contrary, the increase seems to be related to colleges that offer two-year programs, mainly in the human sciences. The fact that these courses last for two years only and do not require sophisticated infrastructure allows for cheaper fees when compared to traditional courses. (p. 104)

Santos (2010), in turn, has pointed out that:

The main issue is not the fact that there has been an increase in the number of private colleges. That has happened because there has been a corresponding increase in demand. What is important is what kind of teaching they are offering. In other words, the quality of what they are teaching. Federal policies addressing this issue seem to be of crucial importance.

Similarly, Brandão (2005) has argued that "Ultimately, Prouni entails the transfer of public money to private colleges, with no guarantee that they will enhance quality" (p. 78). In the same sense, McCowan (2007) has pointed out that:

Alongside [the good private universities] a new group of profit-making . . institutions has emerged, with a very different orientation from both public and traditional private institutions. They are primarily teaching institutions ... with an emphasis on rapid expansion and cost efficiency, employing aggressive marketing strategies in response to increasing competition. ... These university centers [providing] lower-cost tuition, often of questionable quality, ... are the institutions in which the bulk of university expansion is occurring. (pp. 584-585)

Another criticism regarding Prouni refers to the fact that it addresses only the question of enrollment and does not pay the necessary attention to student retention. Referring to that, Carvalho (2006) has stated that Prouni is in fact a palliative solution, based on recommendations of the World Bank, which offers benefits instead or rights to high school graduates. In her view, it may stimulate access to higher education, but it does not guarantee retention and conclusion of courses (p. 994). 
Catani, Hey, and Gilioli (2006), for their part, have argued that the biggest problem with Prouni is that it fails to address the issue of student retention in schools. According to the authors, student retention is an essential element of higher education policies and cannot simply be delegated to the private sector (p. 134). Equally, Valle (2009) has contended that what Prouni does is to promote access, without thinking about retention. In that sense, he argued that "the program is more of a benefit than of a guaranteed right, which makes the situation more critical, given the questionable quality of some private IHEs" (p. 93).

\section{Policy Recommendations}

As already stated in this essay, the Prouni - University for All policy was implemented in Brazil, aiming to promote social justice by expanding the access of the underprivileged to IHEs. Even though the policy has yielded significant quantitative results, there has also been substantive criticism regarding more investments in public universities, the quality of what is being offered, and student retention. Therefore, recommendation seems necessary to ameliorate efforts regarding the promotion of access to higher learning in the country.

Initially, it is crucial to understand that Prouni is in fact a follow up policy related to the first serious attempts to tackle the historical neglect of education in Brazil. Those attempts started in the early 1990s, with the implementation of policies that aimed to increase elementary and secondary school attendance in the country. In 1991, 24 million children (ages 7 to 14) attended elementary school in Brazil. One and a half million students (ages 15 to 17) attended high school (INEP, 1991-1995, p. 18). In 2008, those figures had risen to 32 million (94.9\% of the age group) for the former group and 8.4 million (48\% of the age group) for the latter (Civita, 2009, pp. 218-219). In other words, whereas the government has succeeded in placing a significant number of children in school—which is admirable-, there has been little concern for the quality of the education those children are receiving. As a result of the poor standards of the educational quality they receive in schools, children are not able to pass the entrance exams for public free-of-charge universities. In this context, the first recommendation is that the government implement programs and policies directed to improving quality in public elementary and secondary schools on a national level. Those policies should focus primarily on the following items:

Teacher training - It is of crucial importance that all possible efforts be made in order to enhance teacher training. After all, teachers are the primary sources of knowledge in the classroom. If teachers are unprepared, quality will be lacking. In this sense, programs that focus on teaching methodology, techniques, and strategies as well as courses regarding the use of modern technology such as computers and the Internet in the classroom are essential. Equally essential are the provision of courses with the purpose of reviewing and expanding content knowledge, so that teachers are constantly enhancing their capacities.

Facilities - Policies should also be implemented in order to improve school facilities. That includes more equipped classrooms, larger computer-based libraries, adequate physical education space, and all other necessary improvements that are needed in order to attract and retain students.

Salary - Most importantly, teacher salaries should be raised in order to stimulate outstanding work and promote teacher retention. One of the main reasons - if not the most important one-teachers often end up going into another career is that they are not properly paid. Thus, any other effort to improve quality will fail if teachers are not better paid.

If quality in elementary and secondary schools improves, a direct result will be that more students will be able to succeed the entrance exams and enter the public free-of-charge universities. Consequently, there will be a need to increase their capacities to accommodate the increasing demand. Thus, a second recommendation is that policies and programs to expand the capacity of public IHEs be implemented. As in primary and secondary schools, those policies should include federal investments in faculty training, improvement of facilities, and also salary increase. Furthermore, they ought to provide federal funds for massive investment in research and development to increase the knowledge base, which would in turn allow for a better understanding of the problem.

Finally, a third recommendation is needed with regard to student retention. In order to promote retention, inducements need to be targeted to the social disparities that permeate Brazilian society, given that school abandonment is mostly due to the fact that students are not able to balance their financial responsibilities with college costs. Nevertheless, if policies regarding investments in primary and secondary schools, coupled with programs to expand capacities of public universities are implemented, the problem of student retention will tend to be ameliorated. After all, stimulating and inspiring quality education and well-equipped school and campuses are both necessary conditions to foster retention.

\section{Conclusion}

As outlined previously, serious efforts concerning educational improvements only started in Brazil in the mid 1990s, 
when - after centuries of disinterest-federal policies directed to universalizing elementary and secondary schooling started being implemented. In 2005, in the wake of those policies, the government adopted the Prouni program in order to promote access to IHEs in the country. Although the initiative is praiseworthy, more remains to be done: The country's ultimate goal should be universal, high quality education. Such is the intent of the recommendations provided in this paper.

\section{References}

Algebaile, M. E. B. (2007). Expansão da educação superior: Traços de uma inclusão seletiva no cenário educational brasileiro [Expansion of higher education: Traces of selective inclusion in the Brazilian educational scenario]. In Vieitez, C. G. \& Barone, R. E. M. (2007). Educação e políticas públicas: tópicos para o debate (p.104). Araraquara, SP: Junqueira\&Marin.

Basic Cycle for Higher Education Act of 1969, S. 464, 43 ${ }^{\text {rd }}$ Cong. (1969). [Online] Available: http://www6.senado.gov.br/legislacao/ListaTextoIntegral.action?id=93757

Carvalho, C. H. A. (2006). O Prouni no governo lula e o jogo político em torno do acesso ao ensino superior [Prouni in Lula administration and the political game around access to higher education]. Educação Social, 17(96), 993-994. [Online] Available: http://www.scielo.br/pdf/es/v27n96/a16v2796.pdf

Castro, A. M. D. A. (2006). Ensino superior no Brasil: Expansão e diversificação [Higher learning in Brazil: Expansion and diversification]. In Neto, A. C., Nascimento, I. V., \& Lima, R. N. (2006). Politica pública de educaçao no Brasil: Compartilhando saberes e reflexões (p. 122). Porto Alegre, RS: Sulina.

Catani, A. M., Hey, A. P., \& Gilioli, R. S. P. (2006). Prouni: Democratização do acesso às instituições de ensino superior? [Prouni: democratization of the access to higher education institutions?]. Educar, 28, 134. http://dx.doi.org/10.1590/S0104-40602006000200009.

Civita, R. (Ed.). (2009). Almanaque abril 2010 [Abril almanac 2010] (pp. 118-222). São Paulo, SP: Abril.

Cunha, L. A. (2000). Ensino superior e universidade no Brasil [Higher learning and university in Brazil]. In Lopes, E. M. T, Luciano, M. F. F., \& Veiga, C. G. ( ${ }^{\text {nd }}$ ed.) 500 Anos de Educação no Brasil (pp. 152-153). Belo Horizonte, MG: Autêntica.

Cunha, M. I. \& Pinto, M. M. (2009). Qualidade e educação superior no Brasil e o desafio da inclusão social na perspectiva epistemológica e ética [Quality and higher education in Brazil and the challenge of social inclusion in the perspective of epistemology and ethics]. RBEP, 90(226), 582. [Online] Available: http://www.rbep.inep.gov.br/index.php/RBEP/article/viewFile/1551/1280

Ferraro, A. R. (2002). Analfabetismo e níveis de letramento no Brasil: O que dizem os censos? [Levels of illiteracy in Brazil: What do censuses say?]. Educação Social, 23(81), 34. Campinas, SP: Educação e Sociedade. http://dx.doi.org/10.1590/S0101-73302002008100003.

IBGE. (2009). Síntese dos indicadores sociais [Synthesis of social indicators]. Brasilia, DF: Author. [Online] Available: http://www.ibge.gov.br/home/presidencia/noticias/noticia_visualiza.php?id_noticia=1476\&id_pagina=1

INEP. (1991-1995). Sinopse estatística da educação básica [Statistical synopsis of basic education]. Brasília, DF: Author.

http://www.inep.gov.br/download/catalogo_dinamico/estatisticas/mioloSinopse1991-1995.pdf

INEP. (2008). Censo da educação superior [Higher education census]. Brasília, DF: Author. [Online] Available: http://www.inep.gov.br/superior/censosuperior/evolucao/evolucao.htm

Maculan, N., Ribeiro, C. C., \& Haddad, F. (2006). Program Prouni: Changing the panorama of access to higher education in Brazil. IAU Horizons, 12(2), 9. [Online] Available: $\mathrm{http}: / /$ www.iau-aiu.net/newsletters/iaunew12-2-en.pdf

Mancebo, D. (2004). Reforma universitária: Reflexões sobre a privatização e a mercantilização do conhecimento [University reform: Reflections on the privatization and commoditization of knowledge]. Educação Social. 25(88), 852-853. [Online] Available: http://www.scielo.br/pdf/es/v25n88/a10v2588.pdf

McCowan, T. (2007). Expansion without equity: An analysis of current policy on access to higher education in Brazil. Higher Education, 53, 584-589. http://dx.doi.org/10.1007/s10734-005-0097-4.

MEC. (2008). Prouni: Programa universidade para todos [Prouni: University for all]. Brasilia, DF: Author. [Online] Available: http://Prouniportal.mec.gov.br/index.php?option=com_content\&view=article\&id=124\&Itemid=140

Niskier, A. (1989). Educação Brasileira: 500 anos de história, 1500-2000 (pp. 355-356). São Paulo, SP: 
Melhoramentos.

Prouni - University for All Act of 2005, S. 11096, 52 $2^{\text {nd }}$ Cong. (2005). [Online] Available: http://www.planalto.gov.br/ccivil_03/_ato2004-2006/2005/Lei/L11096.htm

Santos, J. D. (2010, October 15). Interview by Abrahao Andre de Araujo. Prouni and Public Policy in Brazil. [Online] Available: http://abearaujo.multiply.com/journal/item/64

Valle, M. J. (2009). Prouni: Política pública de acesso ao ensino superior ou privatização? [Prouni: Public policy for access to higher education or privatization?] (Master's thesis, Universidade Tuiuti, Paraná, Brazil). [Online] Available: http://revista.unibrasil.com.br/index.php/retdu/article/viewFile/72/102 